\title{
DEVELOPMENT OF PRODUCTION OF VARIOUS ORNAMENTAL FLOWERS AND PROCESSED PALM SEED PRODUCTS AT RAWA BUAYA VILLAGE - WEST JAKARTA
}

\author{
Tukhas Shilul Imaroh \\ Faculty of Economics and Business, Mercu Buana University \\ tukhas.shilul@mercubuana.ac.id
}

\begin{abstract}
Activities to encourage people to be creative and independent with entrepreneurship can be done through partnerships that will provide convenience and become more excited. Rawa Buaya village community partner with the PKK and Ruang Publik Terpadu Ramah Anak (RPTRA), conduct entrepreneurial activity for economic independence and help one of Jakarta government programs. Residents carry out the production process if there is a desire or order, therefore the scale of production and marketing needs to be improved. Production process activities carried out have not been continuously indicated that the community does not understand entrepreneurship. For this reason, an understanding of entrepreneurial knowledge is needed in the production process, starting from the right production planning, readiness of raw materials and product diversification in building a business independently of the community, especially the residents of Rawa Buaya village. The activity begins with the provision of entrepreneurial understanding, the right production process and the need for product diversification so that it can make a continuous effort to increase economic independence. Entrepreneurial become the motor of economic and capable of creating jobs, more hope will boost economic growth and contribute to the reduction of unemployment through various development activities production of ornamental flowers and seeds of refined products in the village of Rawa Buaya Palm is expected to increase the number of SME entrepreneurs.
\end{abstract}

Keywords: Entrepreneurial knowledge, production process, and product diversification.

\section{INTRODUCTION}

The population of Indonesia currently reaches approximately 255 million, on the one hand the number of unemployed and poor population increases every year along with the increase in population, on the other hand the proportion of the number of Indonesian 'entrepreneurs' who actually contribute to 'job creation' is still very low that is only around 1.65\% (Ministry of Cooperative and SME Ministry of Education data, 2015). Ideally the number of entrepreneurs must be at least $2 \%$ of the total population of a country, for example the number of entrepreneurs in the United States reaches $12 \%$ of the total population, Singapore is 7\%, China and Japan are also around 10\%; Malaysia 5\% and Thailand 4\%. Thus Indonesia still lacks entrepreneurs / entrepreneurs at least $0.35 \%$ of the total population of the minimum standard. Empirical studies show that only through the hands of an 'entrepreneur / entrepreneur' will be created 'jobs', they become 'the motor of economic drive' and in their hands economic growth will accelerate which will ultimately contribute to the reduction of unemployment. These conditions indicate the need for encouragement to improve entrepreneurship debriefing to the community, which in turn is expected to be born new entrepreneurs, for those who have become entrepreneurs can be more advanced, and for community leaders can be as a media cadre of prospective entrepreneurs in Indonesia.

Entrepreneurial activity is one of the activities to meet the needs of human life, given the limited resources that exist or do not match the number of goods and services available compared to thenumber of human needs. Human efforts to meet the needs in order to maintain life are called economic activities. Fulfillment of life needs always requires production work, which is an activity to change an object, natural or social to be another and useful for life. Activities that generate added value will be owned by 
the entrepreneurial spirit. The entrepreneurial spirit is the life of a life in entrepreneurship which in principle is the attitude and behavior of entrepreneurship by being shown through the nature, character, and character of a person who has a willingness to creatively create innovative ideas into the real world (Hartanti 2008).

Some factors that determine the formation of entrepreneurs are the character of entrepreneurship that is devoted to someone, entrepreneurial ability and entrepreneurial commitment that needs to be the focus of coaching. Forming and fostering the character of entrepreneurship is needed in order to display and grow entrepreneurs. Allows the nature of a person to become an entrepreneur or not spread to: a) the nature of a strong desire to stand alone; b) the nature of taking risks; c) the nature of learning from experience; d) ready to face competition; e) the nature of hard work; f) high selfconfidence, g) the nature of the need for high achievement, creative, innovative, etc.

Entrepreneurship is obtained either formally or through non-formal learning such as: internship experience, namely 'questions that can be done from entrepreneurial traits that have existed since birth, and it will be a supporter of the formation of entrepreneurs. It is expected that if someone has a strong and perfect entrepreneurial character with sufficient entrepreneurial ability, then it will lead to a strong commitment (commitment) to entrepreneurship, these people will linearly continue to foster their careers into entrepreneurs.

\section{Problem}

Based on the results of focus group discussion (FGD), interviews with Village Office Officers, Chairmen and Members of the PKK, MSMEs from Rawa Buaya Village obtained information, among others, as follows: that business owners do not yet have entrepreneurial knowledge, the right production processes and the need for diversification of products in realize business sustainability for economic independence. The orientation of the business owner is still very local, doing business if there is an order not yet committed to the continuity of the business.

\section{THEORITICAL FRAMEWORK}

The realization of small businesses carried out based on the entrepreneurial spirit which is a personality and has been internalized through entrepreneurial values for people who conduct business activities. Business activities require awareness or understanding of entrepreneurship, production processes, and a strong desire for business sustainability. Kuntowicaksono (2012) states that knowledge is a person's understanding of entrepreneurship with a variety of positive, creative and innovative characters in developing business opportunities into an exhibition that benefits him and its consumers. Nursito and Nugroho (2013) stated that "entrepreneurial knowledge as a level of knowledge as a result of learning after the entrepreneurial education process is needed to start and live a business". Suryana and Bayu (2010: 6)

According to Tjiptono (2008: 132), diversification is an effort to find and develop new products, or both, in the context of growth, increased sales, profitability, and struggle. According to Fitriani, Sarono and Widodo (2011), the notion of diversification is an effort to find and develop new products, or both, in the context of growth, increased sales, profitability, and struggle. Thinking ability to develop reliable products, entrepreneurial spirit, sensitivity to technological and environmental developments, product development or diversification determine the development of business and the ability of an entrepreneur to join. Based on this understanding, it is stated that business diversification is carried out by finding and developing new products and products by maintaining products that are suitable for the needs of consumers in pursuing growth targets, increasing sales, profitability and tactics.

The Production Process according to Sofyan Assauri (2016: 123) is "an activity that involves human power, materials and equipment to produce useful products. The production process according to Agus Ahyari (2010: 65) is "the production process is a way, method or technique of how new useful creation activities or additional benefits are carried out. The production process according to Reksohadiprodjo (2010: 153) is an activity to create or add an item or service by using existing factors such as labor, machinery, raw materials, and funds to be more useful. Based on the understanding that the production process as an activity adds value to an item or service through the production factors that are owned, among others, humans, machines, raw materials, funds, technology and information. 
In order to achieve economic growth in global uncertainty, it is necessary to empower small businesses that are expected to be able to develop production. In accordance with the government program targeted 5 million new entrepreneurs up to 2025 by developing human resources for the advancement of national entrepreneurship. As an effort to increase entrepreneurial capacity, the government strives to improve the quality of human resources in entrepreneurship with three stages, namely nursery, forging, and development. All these activities need good guidance, which can be done formally or informally. Activities become more optimal by conducting partnerships

\section{METHOD}

The target audience of the community service program activities was organized from the production development program of various ornamental flowers and palm kernel processed products from prospective entrepreneurs, business people, youth, and community leaders related to micro and small businesses at Rpetra Sugriwa jl Taman Sugriwa RT 09 / RW 09 Kelurahan Rawa Buaya, West Jakarta, from November 2017 to March 2018. It is expected that the community in Rawa Buaya Urban Village will implement the management of business activities as they should to face increasing business competition, be able to increase their business sustainably, be able to produce, be able to innovate by creating diversification products, and manage resources effectively. Implementation will be carried out in stages.

\section{Preparation Phase}

This preparation focused on surveys, interviews, and focus group discussions (FGDs) on the target location communities, to get feasibility in coaching activities and help the community to develop economically and independently. In the preparatory phase, the meeting began with a meeting with the village officials, with complete data collection, administration, followed by meeting the ornamental flower businessman and palm kernel processing in order to communicate effectively.

\section{Implementation Stage (Counseling, Discussion, and Coaching)}

The implementation phase is the stage that requires the most time and mobilizes the necessary resources: Prepare references and literature in accordance with the needs of counseling and fostering ornamental flower business and palm kernel processing for economic independence. Carry out counseling and business coaching in accordance with the schedule and time of the stages of business development of ornamental flowers and palm kernel processing for economic independence. How to: 1) Build awareness of the need to have a business and business sustainability for economic independence, 2) Strengthening business, understanding production process with the availability of raw materials, production machinery with the right capacity, quality products and the right packaging. 3) The need for product diversification for business sustainability and fulfillment of consumer desires. All this is done to support economic independence.

\section{Evaluation and Reporting Phase}

At this stage an evaluation was carried out in achieving the targets that were expected to see the success of fostering various decorative flowers and processing of palm seeds in the Rawa buaya village. Along with the preparation of reports on the results of community service to be accounted.

\section{Activity Method}

The method of carrying out activities in solving the problems of the target audience of business people, prospective business actors, youth, and community leaders related to business activities in the Rawa Buaya West Jakarta village is as follows:

\section{Lecture, Discussion and Question and Answer}

This method is chosen to convey important concepts to be understood and mastered by business development participants. The use of this method with the consideration that the lecture method combined with audio and video can provide a relatively large amount of material in a solid, fast and easy manner. The material provided in the form of entrepreneurship knowledge, production processes, and product diversification efforts as one of the business development strategies for economic 
independence. It is expected that the delivery of material provides additional insight, understanding, and motivation to have a business and economic independence.

\section{Questionnaire}

This method is done to find out the understanding before and after being given an understanding through lecture activities, discussions, and questions and answers.

\section{Monitoring, Evaluation and Reporting}

This method was chosen to monitor the extent of understanding knowledge about entrepreneurship, the process of product production and diversification, so that an entrepreneurial spirit is formed and able to do business in a sustainable manner. Make a complete written report regarding the results of the activities of fostering ornamental flower business and processing of palm seeds to the head of the community service center for accountability.

\section{RESULT AND DISCUSSION}

\section{Field Survey}

The initial stage of the coaching process is carried out mapping and focus group discussion (FGD) with Village Office Officers, Chairmen and Members of the PKK, UMKM actors in Rawa Buaya Village, conducted at the Rawa Buaya village office by producing information about the ability of the beginner business community with various creativity. making flowers from plastic materials and obtaining information on the responsible person of the Rawa Buaya village and the organizational structure of the organization

\section{Results of Implementation of Activities}

The results of community service are explained in 3 aspects, namely: attendance of participants, participation and sincerity of participants, and evaluation of socialization.

Attendance of participants: The targets involved in this activity are business actors, callon business actors, youth and community leaders who are related to SMEs in the Rawa Buaya Village. In the implementation of the activities carried out in RPTRA Sugriwa in Jl. Taman Sugriwa RT 09 / RW 09 the number of participants was 42 people according to the invitation.

Participant participation and convenience: Participants' participation and sincerity can be said to be good. This can be seen from the sincerity of the participants in participating in the activities, as well as active discussion and question and answer among the participants by bringing many ideas and desires, Participants actively responding to the speaker in the delivery of the material.

Training Evaluation: This evaluation includes the extent to which the understanding of business people, prospective entrepreneurs, youth community leaders related to entrepreneurship in the Rawa Buaya Village regarding entrepreneurial knowledge, understanding the production process and the need for product diversification in business continuity for economic independence related to entrepreneurship.

The following will be evaluated about the participant's profile related to entrepreneurial knowledge, the production process, and the need for product diversification and the extent of perception of PKK mothers in Rawa Buaya Urban Village to build business sustainability for economic independence.

\section{Profil Peserta.}

Profil peserta pembinaan usaha:

\begin{tabular}{|c|c|c|c|c|c|r|c|}
\hline Usia & jumlah & $\begin{array}{c}\text { Pendi } \\
\text { dikan }\end{array}$ & jumlah & Pengalaman & Jumlah & Jenis Usaha & Jumlah \\
\hline $21-30$ & 8 & SMP & 15 & $<1$ thn & 19 & Indust Rumah & 6 \\
$31-40$ & 15 & SMU & 12 & $1-3$ thn & 11 & Tangga & 5 \\
$41-50$ & 12 & D3 & 5 & $4-6$ thn & 7 & Bisnis On Line & 14 \\
$51-60$ & 5 & S1 & 10 & $7-10$ thn & 5 & Bunga hias & 17 \\
$>60$ & 2 & & 42 & $11-20$ thn & 0 & plastik & 3 \\
Total & 42 & & 42 & & Makanan/ & 42 \\
& & & & & & & Minuman \\
& & & & & & & \\
\end{tabular}




\section{Knowledge, Production Process and Product Diversification for Economic Independence}

P2M activities carry out coaching in the Rawa buaya village in the business community group. This activity begins with a pretest to find out entrepreneurship knowledge, production, and product diversification in encouraging business sustainability. Further can find out the hope of economic independence. As an entrepreneur, you will definitely experience business competition, by having a commitment, your business will continue to be sustainable.

The following are some of the statements that were responded to by entrepreneurs in the Rawa buaya village:

Questionnaire
\begin{tabular}{|l|l|c|c|}
\hline No & \multicolumn{1}{|c|}{ Pernyataan } & BENAR & SALAH \\
\hline 1 & Entrepreneurship as one of the family's economic independence & V & \\
\hline 2 & Entrepreneurship as a trading activity for independent economics & & $\mathrm{V}$ \\
\hline 3 & Entrepreneurship can continue to form independence which has a clear purpose & $\mathrm{V}$ & \\
\hline 4 & Entrepreneurial effort to fulfill the desire if there is an order & & $\mathrm{V}$ \\
\hline 5 & $\begin{array}{l}\text { Production planning is needed in business activities when operational activities } \\
\text { are carried out }\end{array}$ & $\mathrm{V}$ \\
\hline 6 & $\begin{array}{l}\text { The production planning function can guarantee consistent sales and } \\
\text { production }\end{array}$ & $\mathrm{V}$ & \\
\hline 7 & Products depend on selling only one type with the aim of reducing risk. & $\mathrm{V}$ & \\
\hline 8 & $\begin{array}{l}\text { Small and medium enterprises need to vary the types of products to increase } \\
\text { profits }\end{array}$ & & $\mathrm{V}$ \\
\hline 9 & $\begin{array}{l}\text { One of the efforts to empower SMEs with business sector development through } \\
\text { KUB (joint business group), }\end{array}$ & $\mathrm{V}$ & \\
\hline
\end{tabular}

Through filling out a simple questionnaire before carrying out the next activity, namely the provision of materials and further discussion in a series of community service activities in the Rawa buaya village, showing varied filling results. The results of the calculation of answers / responses from 42 participants with the results of the answers / responses from the coaching participants before the presentation of the material show that:

The first statement as a whole gives the "True" response meaning that you agree that entrepreneurship provides an alternative to a family independent solution. Entrepreneurial statement as a selling activity was responded by 3 people who claimed to be wrong, meaning that it is true that entrepreneurs do not have to sell themselves, their knowledge of these 3 people is good. But in this case there are still many (39 people) who state that it is true, meaning that entrepreneurship is the same as selling, if not selling means that there is no incoming funds, this is not an entrepreneurial spirit. Entrepreneurs must have clear objectives, all have agreed, knowledge about the need for clear goals that are good.

In the fourth statement, entrepreneurs do business to fulfill their wishes if there is an order, meaning that they do business activities if there is an order. This statement was responded to by 10 people who stated wrong / incorrect, the rest did business / business activities if there was an order. This condition indicates that the coaching participants are reactive / waiting for someone to order or come and make or the rest if there is no order means not doing business / business. As an entrepreneur, it is necessary to have a strong plan to develop the business and not wait for consumers to order. Production planning is needed in business activities, when operational activities are carried out. In this statement there were 7 people who said the answer was wrong, meaning that only 7 people understood the need for planning before the activity began, while there were still many or 35 people considered the need for planning before the activity began. Employers need plans before activities begin. Production planning in the production process activities can guarantee consistent sales and production. This statement gives a completely correct response that planning is needed for consistency in doing business.

Production depends on selling just one type with the aim of increasing risk reduction. there were 27 people who gave the right response, this showed a lack of creativity so there was no need for product diversification. Small and medium businesses need to vary the types of products to increase profits Small and medium businesses need to vary the types of products to add to the benefits of this statement. There are 7 people who give false statements, considering that they have not received clear 
information or have not been educated. increase profits. One of the efforts to empower SMEs by fostering certain businesses and regions through KUB (joint business groups), generally understands the simplicity and limited space for SMEs.

Some responses have not shown the entrepreneurial spirit, considering that there is not much understanding about entrepreneurial knowledge, it is still necessary to add knowledge of the production process and the need for product diversification for economic independence. it is necessary to implement commitments in doing business. These conditions need to be given socialization and coaching in entrepreneurship. Coaching activities begin with the provision of material on entrepreneurial knowledge, production processes and product diversification. For business sustainability and economic independence.

Some evidence of the implementation of activities as follows: Coaching activities with the delivery of entrepreneurial knowledge material, in the hope of increasing understanding of knowledge to encourage people to develop business continuously with high commitment. In the activity of delivering material, it is done interactively and spiritually. People have high curiosity. There are participants who wish to obtain business licenses and patents, but still not enough for business sustainability, considering that raw materials are still uncertain. This condition also shows the lack of entrepreneurial understanding of the need for the availability of raw materials in the production process. Exactly with the material production process, that production activities need to plan raw materials, machinery, product quality. The enthusiasm of participants who need guidance to continue to have a sustainable business. This condition needs to be supported by an understanding of the importance of product diversification, considering that there are still many participants who are afraid of the risks with the many products provided. Understanding product diversification is not always a different product, but with market development or with the development of both.

After submitting the material, the questionnaire was filled out as a post-test activity, the results showed that there was an increase in understanding of entrepreneurial knowledge, the production process and diversification for economic independence. Based on the results of the processing of answers / responses from the coaching participants after giving the material, it shows that: the first statement as a whole gives the "True" response. In this statement all have understood that entrepreneurship provides an alternative independent solution to the family. No different from before the delivery of material. Entrepreneurial statement as a selling activity, changes or additions to a number of participants to 21 people who stated wrong, meaning that entrepreneurs are not only as sellers, but more than selling activities. After submission of the material shows additional understanding, changes in understanding cannot be done instantaneously or only once but are needed periodically or repeatedly and coaching. Entrepreneurs must prepare starting from the acquisition of raw materials to smooth the production process, so that production does not occur for a moment / must be considered sustainability production. Next the process of production and quality, reaching the product into the hands of consumers, this is an entrepreneurial spirit. Entrepreneurship must have clear goals, all have agreed, knowledge of the need for clear goals is good. All activities must always be based on clear objectives.

In the fourth statement, Entrepreneurial conducts business to fulfill the desire if there is an order, which means doing business if there is an order. This statement shows the difference between before the delivery of material with a setting given business and production material. There is an increase in understanding to 21 people or half of the participants who stated wrong / incorrect. This condition shows that entrepreneurs are not only in production if there is a message, but the need to carry out production activities continuously, the finished product must be actively marketed using facilities / media, both electronic, print, and direct marketing. Next, good planning must always be done. Production planning is needed in business activities, when operational activities are carried out. After the presentation of the material showed an increase in understanding, in this statement, additional participants who responded with wrong answers contained 22 people, more than half of the total participants, meaning understanding the need for planning before the activity began not when production was running. Employers need to do production planning before activities begin. Planning as an initial part of production activities, raw material readiness must be an initial consideration in production. Production planning can guarantee consistent sales and production. This statement provides an overall response confirming that planning is needed for consistency in doing business.

Production that does not depend on the sale of one type only with the aim of increasing profits and reducing risk, or the need for product diversification. There were changes in responses to 8 people 
who gave the right response, this shows that every production activity needs to diversify products to reduce saturation and the risk of production cessation. Small and medium-sized businesses need product variations in increasing profits, generally understanding and showing changes or differences with before giving material that is more than half of the participants present, this shows very significant understanding. one of the efforts to empower SMEs by fostering certain business fields and regions through KUB (joint business group), in general understanding the simplicity and limited space for SMEs. The overall response states that SMEs must make joint efforts / mutual cooperation to develop business.

Based on the comparison of the responses of the pre-test and post-test questionnaires, some showed an understanding of entrepreneurship and the production process, but the need for diversification of business products for business independence was still less supportive, considering that they were still afraid of the risks that might occur. Including still interpreting the business according to the order. This is the role of providing information through the presentation of production activities that are needed by planning and understanding of the willingness of the market so that business continuity becomes important.

The community of Rawa buaya village, has a lot of creativity in making ornamental flowers and palm kernel processing, this activity is carried out when there is a will on the sidelines of other activities or when receiving orders. With the explanation that entrepreneurship is very necessary for sustainability, as well as the strategy of the production process, giving encouragement to the people in Rawa Buaya. Ornamental flower and palm kernel flower production activities are needed to prepare sufficient raw materials for sustainable and economic independence. The constraints experienced are that palm fruit seeds are still limited and do not have a garden or supply network, this needs to be prepared and built in a supply network. Ornamental flowers are sufficient supply because the raw material is easy to obtain.

In order to enlarge the business, it is needed togetherness and coordination with similar entrepreneurs, as well as the ability to market. In this activity also has been given an explanation of efforts to market through print and electronic / social media, as well as togetherness with the PKK Innovation and creativity in making ornamental flowers and processed palm seeds from the people in Rawa buaya have increased a lot. This condition continues to require coaching so that it continues to have consistency and sustainability and needs to be reminded of the mindset of an entrepreneur, among others, increasing turnover and developing. It is necessary to remind that production activities are not only waiting when there are orders. This can be done, considering that P2M Mercubuana University has collaborated with the Rawa buaya village

The results of coaching participants' creation of various ornamental flowers and processed palm seeds showed their creativity by making flower creations from plastic materials and processed palm seeds made of palm fronds with various colors such as fruit fro like the following picture:
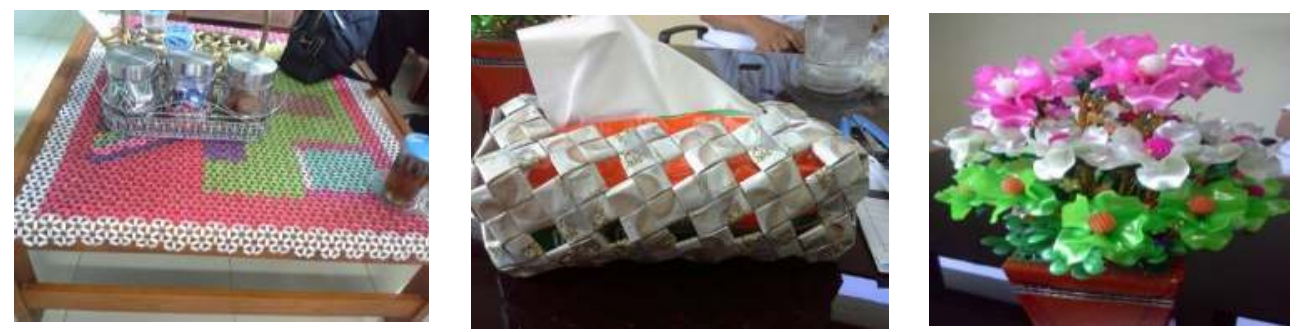

Figure 1. Aneka kreasi dari bahan plastik 

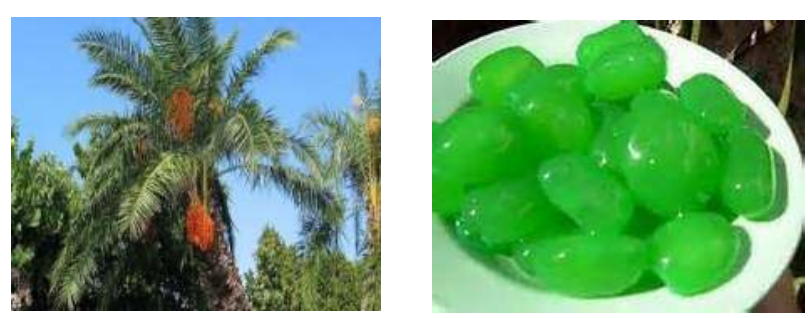

\section{CONCLUSION}

Figure 2. Kreasi dari buah palm

Based on the exposure, discussion, and questionnaires on pre-test and post-test on entrepreneurial knowledge, the production process and product diversification to form economic independence in the business as well as an evaluation tool for the explanation of building SME business sustainability in Rawa Buaya, West Jakarta can be concluded:

Participants understand the need for entrepreneurial knowledge in economic independence. Entrepreneurship is not just selling activities. Entrepreneurial activities in building business sustainability as an effort of economic independence with the most important elements in the business of ornamental flowers and processed palm fruit seeds are:

a. Entrepreneurial knowledge about the ability to understand the pattern of self and sou as an entrepreneur, applying basic values of honesty, as well as responsibility for business.

b. The ability to understand the production process for business sustainability through production planning, the adequacy of raw materials, especially palm fruit seeds, remembering is still very limited, so that togetherness is needed and build a supplier / supplier network as a necessary effort in solving constraints in palm kernel processing in SME businesses.

The ability to produce goods continuously in order to support the achievement of business success and the need for diversification with the diversity of ornamental flower products in various forms and media, various processed palm seeds.

\section{REFERENCE}

Alma Buchari. (2006). Kewirausahaan, Edisi Reviai. Bandung : Alfabeta.

Curtis, S., \& Wright, D. (2001). Retaining employees-the fast track to commitment. Management Research News, 24(8/9), 59-64.

Prawironegoro, D. (2010). Filsafat Ilmu: Kajian Tentang Pengetahuan Yang Disusun Secara Sistematis dan Sistemik Dalam Membangun Ilmu Pengetahuan.

Tjiptono, F., Chandra, G., \& Adriana, D. (2008). Pemasaran strategik. Yogyakarta: Andi.

Gibson, James L.; Ivancevich, Jhon M.; Donelly, James H.;Konopaske, Rober. (2009). Organization, Bahavior, Structure, Process, Edisi $13^{\text {th }}$ ed. Boston : McGraw-Hill

Hendrojogi. (2007). Koperasi: Asas-asa, Teori, dan Praktik. Jakarta : Raja Grafindo.

Hjelle, L. A., \& Ziegler, D. J. (1992). Personality theories: Basic assumptions, research, and applications. McGraw-Hill Book Company.

Singgih, S. (2000). Buku Latihan SPSS Statistik Parametrik. Jakarta. Gramedia.

Shermon, G. (2004). Competency based HRM: A strategic resource for competency mapping, assessment and development centres. Tata McGraw-Hill Education.

Sopiah. (2008). Perilaku Organisasi.Yogtyakarta : Andi. 
Sugiyono, M. P. P. K., \& Kuantitatif, P. (2008). Kualitatif dan R \& D, cet. Bandung: Alfabeta.

Suparman, A. (2012). Desain instruksional modern: panduan para pengajar dan inovator pendidikan. Jakarta: Erlangga.

Uno, H. B., Umar, M. K., \& Panjaitan, K. (2014). Variabel penelitian dalam pendidikan dan pembelajaran. Jakarta: Ina Publikatama.

Woolfolk, A. E. (1993). Educational Psychology. Boston,: Allyn \& Bacon. 